\title{
It's a Small World: Incorporating Service Learning into International Relations Courses*
}

\author{
Amy S. Patterson, Elmhurst College
}

$T_{\text {and }}^{\text {ear }}$ eachers of international relations and comparative politics courses face a difficult task because young people are generally not interested in politics and because Americans lack knowledge and concern for international issues. In a recent $P S$ article, Sheilah Mann (1999) reported that in 1998 only $26 \%$ of first-year undergraduate students claimed that "keeping up to date with political affairs" is very important, and only $14 \%$ said they had discussed politics in the past year. In 1996 , just $31 \%$ of eligible voters aged 18 to 20 cast ballots in the presidential election (U.S. Bureau of Census 1997). Interest in international politics is even more limited. Only $20 \%$ of Americans follow foreign news through newspapers or television, and Americans have little knowledge about key global events such as the Bosnian civil war and the Middle East conflict (Rourke 1999, 2-4). Further, Americans aged 18 to 24 consistently rank last in their knowledge of global events in surveys of young adults in industrialized countries (Wiarda 1996, 61).

While teachers of international politics face a growing number of students who are uninterested and uninvolved in domestic and international politics, the corporate world is increasingly demanding that college graduates have international experiences, cross-cultural training, and exposure to global economic and

\footnotetext{
Amy S. Patterson is assistant professor of political science at Elmhurst College. She has published articles on civil society and citizenship in Senegal in The Journal of Modern African Studies and Africa Today. She recently received an APSA grant to complete research on the impact of Senegal's decentralization program on women in local politics.
}

political issues. The world outside of academe has pushed many institutions to require their students to take courses that focus on international issues. These requirements provide opportunities for teachers of international politics to demonstrate the relevance of international phenomena to their students' personal and professional lives. To achieve their objectives, teachers need creative techniques that engage students and make international politics comprehensible. This article outlines one such technique: the infusion of service learning into an international relations course.

In 1995, my institution revamped its general education curriculum and included a "global society" requirement. POL 306: The Politics of International Relations meets this requirement, in addition to serving political science majors. The course is intended to introduce students to the concepts and theories of international relations and to encourage students to value and practice responsible global citizenship. The mixture of majors and nonmajors in the class necessitates that I use creative teaching techniques to achieve these objectives. I believe the addition of a service experience in 1998 increased the learning of the 11 students in the class.

\section{Design of the Service Learning Project}

Though I had previously incorporated service learning into my American government classes, I realized that I needed to carefully chose the service site for the international relations course and structure the experience so students would not view the service as merely required volun- teer work (Rhoads and Howard 1998). Robert Trudeau (1997) outlined the difficulties his students had linking their service as tutors and soup kitchen assistants to the content of a Latin American politics course. I wanted the service to reinforce select classroom concepts and to challenge the students to develop ideas of global citizenship. I also decided that the service experience had to be a course requirement, since most students at my institution are not risk takers in learning and would not choose to do service learning (Barber and Battistoni 1993).

I am fortunate that my institution has a service learning coordinator and is located in a metropolitan area with many international agencies and peoples from different countries. These factors made it easier to find an appropriate site, and the students were assigned to work with a refugee resettlement nongovernmental organization (NGO). Using $\$ 500$ supplied by my institution's service learning program, the students worked together to purchase a "welcome pack" of household items, ranging from bedding to personal effects, for a Bosnian refugee family. The NGO provided a list of items that the family needed to furnish an apartment, and the students divided the list and shopped in teams for the items. Since they had a limited amount of money, the students had to budget, communicate with each other, and hunt for bargains. ${ }^{1}$ After the students bought the items for the welcome pack, and before the family arrived in the U.S., the students delivered the household goods and set up the family's apartment. On the designated day, some of the students and a translator from the resettlement agency met the family 
members at the airport and helped them move into temporary housing, since their apartment was not ready. Groups of students then arranged with the resettlement agency to informally visit the family several times during the semester. Because I wanted the students to respect the family's privacy, and because the students were not trained in interviewing techniques, I told the students that they should not interview the family members about their experiences during the war or as refugees. (As the students and refugees interacted over time, these issues did arise.) To facilitate coordination of the project, I occasionally gave the class a few minutes to discuss logistics, but the students had to work together outside of class to buy, store, and deliver the items and to arrange their family visits.

\section{Using the Service Experience to Refine and Reinforce Classroom Learning}

Though the service did not explicitly teach the students new international relations concepts, it did help them to refine their ideas on several classroom topics and it helped me to provide the students with concrete examples of global phenomena. Initially, few students in POL 306 saw the value of the service learning experience. Many of the students at my institution are commuters who spend little time on campus, and, despite the fact that they live in a large metropolitan area, most students have had few experiences with other cultures or people from other countries. The service experience challenged their attitudes and routines. To impress upon them how their service reinforced their classroom learning, I specifically asked the students to reference their experiences when we studied the topics of NGOs, human rights, ethnic identity, and global interdependence. I used in-class discussions, group work, and short writing assignments to encourage students to relate their service experience to these topics. The following examples illustrate how the service helped the students to refine their understanding of select concepts in international relations.

\section{NGOs and Global Politics}

In the post-Cold War era, NGOs have emerged as major players in the international realm, often matching states in their ability to influence international relations (Henderson 1998). ${ }^{2}$ The students learned that NGOs lobby international organizations and national governments to affect policy, and that NGOs meet global needs that governments may not have the means or political will to address. However, because NGOs are often portrayed as a homogeneous entity in international relations textbooks, the students did not grasp how NGOs differ in their resources, power, interests, and effectiveness. To help the students disaggregate the "NGO monolith," I asked them to discuss their observations about the refugee resettlement agency they were assisting. How was the NGO organized? Did it appear to have enough resources? What issues did it address? How did it relate to other NGOs?

In class discussions and writing exercises, many students mentioned that on the day the Bosnian family arrived, the apartment was not ready and the agency had to arrange for the family to stay in a hotel. From this situation, the students experienced first-hand how NGOs may lack resources, logistical organization, and manpower to deal effectively with issues. The students learned that the resettlement NGO, like most other similar groups, had little access to government resources and received much of its funding from individual donors; indeed, the agency required the family to pay back the cost of their airline tickets. The students also learned that a second resettlement agency provided the apartment for the refugee family, while a third NGO arranged a job for the father. Through this discovery, students gained new insights into the ways that underresourced NGOs build coalitions to achieve their objectives. The students' experiences with a particular refugee re- settlement agency enabled them to gain a richer understanding about the diversity of NGOs than they could have if they read only the description found in their textbook. Because the students had worked personally with an NGO, they were better able to understand the position such groups occupy in the international realm.

\section{Human Rights}

As one of their assignments, students read the Universal Declaration of Human Rights. It was the service experience, however, that enabled the students to fully appreciate the concept of inherent rights outlined in Article 1 of the Declaration. Because they grew up in the U.S., where the idea of inherent rights is included in the Constitution and reinforced through numerous judicial decisions, the students had never really considered the situation of those who lived under a political system that did not acknowledge basic human rights like the rights to life, liberty, and security. As the refugees told the students about family members and friends who had been driven from their homes or killed in the war, the students became personally aware of human rights conditions outside of their own community and country.

The service also helped the students gain more insights into the complexity of protecting the specific rights outlined in the Declaration. For example, I pointed out that the right to asylum for those persecuted (Article 14) could be invoked as a challenge to state sovereignty, as it often is when a state is pressured to admit refugees into its territory. The students saw this tension between state sovereignty and an individual's right to asylum exemplified in the lives of the refugee family. The family members had been in Germany for five years before coming to the U.S. They had had to leave Germany when the German government asserted its sovereignty over domestic policy and decided that, in light of the Dayton Peace Accords, Bosnian refugees would either have to return to Bosnia or find a third country to take them. The impact of 
Germany's decision on the refugee family was obvious to the students. The family had to move again, gain new language skills, learn about another culture, and make new friends in a different community. Though the students understood that the German government had sound domestic economic and political reasons for expelling Bosnian refugees (as well as some justification once the peace agreement was concluded), the students believed that repatriation to Bosnia was not a safe and humanitarian option and that Germany was implicitly denying the human right of protection to the refugees. Through the specific case of the refugee family, the students gained a richer understanding of how the tension between state sovereignty and the protection of human rights can impact individual lives.

\section{Ethnic Identity}

Though course readings and lectures addressed ethnic identity and ethnic conflict (esp. Gurr and Harff 1994), the service experience gave the students a new perspective on the complex nuances of ethnic identity. As we discussed ethnicity, I asked the students to think about the Bosnian family and the ways that the family members formally and informally identified themselves. What did they call themselves? With whom did they associate? What actions demonstrated their ethnic, religious, or other cultural identities? One student said that though the father was Muslim, he did not seem very devout because he drank beer. Another young woman expressed surprise that both the male and female family members wore Western clothes. These observations provided an avenue through which I could help the students refine their understanding of ethnic identity. My students became aware that individuals define themselves in various ways, and that these ways do not always fit the perception of an ethnic or cultural group that people outside of the group have. The students also learned that ethnic identity is mutable. Family members generally referred to themselves as Bosnians, but also, at different times, defined themselves in terms of religious experiences, their economic situation, or their position as newcomers to the U.S.

Though I had stressed these points about ethnic identity in class lectures, these ideas only became real to the students after they met the refugee family.

\section{Global Interdependence}

The service project provided the students with concrete examples of two aspects of Robert Keohane and Joseph Nye's theory of global interdependence. First, students learned from the textbook and classroom lectures that state borders and state sovereignty can be somewhat porous (Keohane and Nye 1989).

Through their service, students were able to personally experience how political and economic conflicts in one state have

\section{Special APSANet Resources}

on Teaching, Learning, and

Professional Development

Teaching Political Science

www.apsanet.org/teach/

Political Science Syllabi www.apsanet.org/teach/syllabi/

Links to Online Teaching Resources
www.apsanet.org/teach/resources/

Essays from "The Teacher" www.apsanet.org/teach/resources/essays

Service Learning in Political Science www.apsanet.org/teach/service/

\section{CENnet: Civic Education in Political Science www.apsanet.org/CENnet/}

APSA-CIVED: Civic Education Discussion List www.apsanet.org/CENnet/civnetlist.cfm

\section{Graduate Student Connection www.apsanet.org/opps/grad/}

Preparing Future Faculty www.apsanet.org/about/chairs/pff/

eJobs: Jobs in Political Science www.apsanet.org/ejobs/

\section{Professional Opportunities www.apsanet.org/opps}

Careers in Political Science www.apsanet.org/jobplc

Precollege Teaching Resources
www.apsanet.org/CENnet/precollege.cfm

Guidelines for Training Elementary and Secondary Teachers www.apsanet.org/teach/opps/training.cfm 
NOW ONLINE

\section{Audio Stream of Political Engagement and Political Science Panel Presentation}

You can now LISTEN online to the Annual Meeting session, "Roundtable on Political Engagement and Political Science Education: Where Are, and Where Do We Need to Be?" by visiting http://pro.harvard.edu/panels/010/p010009.htm.

The session was chaired by Grant Reeher, Syracuse University. Discussants were: Benjamin R. Barber, Rutgers University, New Brunswick; Jean Bethke Elshtain, University of Chicago; William A. Galston, University of Maryland, College Pare; Elinor Ostrom, Indiana University, Bloomington; Robert D. Putnam, Harvard University; and Theda Skocpol, Harvard University.

This roundtable is a special presentation of PROceedings in the form of an audio transcript. The transcript is in Real Audio format. If you do not have the Real Player installed on your system, a copy of it can be obtained for free at www.real.com. The audio transcript is offered to test the interest of users in nontextual material from the conference. Please send your comments to proceedings@apsanet.org.

ramifications for other states. Their metropolitan area has the largest number of Bosnians in the U.S., and that group's population has been growing rapidly following Germany's adoption of its new repatriation policy. By talking with the NGO official and refugee family, the students discovered that Bosnians inhabit entire neighborhoods of the city and some suburbs in which the students live. The students' understanding of how events in one society impact another society became more profound when they saw an example of this in their own city.

In an unplanned and unexpected way, the service provided my students with an example of a second aspect of the theory of interdependence. The students had read that military force is not the only means states have for exercising power over other states. According to Joseph Nye (1990) states which achieve their goals through attraction instead of coercive force exercise "soft power." The students saw evidence of America's soft power when they first received the list of the items to buy for the welcome pack and noticed that they were to purchase a 24-pack of Coke. One student asked if the group could get a store brand of soda to save money. The NGO official helping the students explained that, in the past, another group had bought a generic brand of soda for another refugee family and the refugees had not known what it was. The student's mundane question led to a long class discussion about how Coca-Cola is recognized globally and is associated with American culture; the product, as well as the image that surrounds it, have shaped beverage consumption everywhere. Additionally, the positive recognition that is associated with this American product can be a source of soft power, or the power of attraction that derives from the American quality of life (Nye 2000). Surprisingly, buying soda gave the students a more concrete understanding of how the recognition of American cultural exports enhances America's image and influence globally.

\section{Encouraging Global Citizenship through Student-Refugee Interactions}

I believe that the most profound impact of the service was that it encouraged students to value other cultures and peoples and to appreciate their role as global citizens. At the end of the semester, I required students to submit five-page essays addressing the following questions:
"How did the service help you to understand the value and dignity of those from another culture?" and "How did your interactions with the refugee family teach you about what it means to be a global citizen?" This essay was worth $10 \%$ of the course grade, and I told students that I would not grade their service itself, but their reflection on the service. I also asked students to share their papers with their peers so they could learn from each other, since they had interacted with the refugees in different ways and had each viewed their service from different perspectives.

One common theme of the essays was that the service project challenged the students to examine their stereotypes of refugees. One woman wrote that she was surprised to learn that one of the family members had studied biology before the war and was interested in attending college in the U.S.; the refugee asked the students for science and math books in English. My student admitted that she had been surprised that the family was so well educated, since the media often portray refugees as poor, huddled masses who individually lack resources and skills. Several students noted the service experience made them reexamine how incomplete media coverage of international issues contributed to their biased ideas about refugees. Another student said that before the service, he had never thought about refugees as people, only as faceless entities. By examining their views of people from another country, the students began to construct a more nuanced conception of the global community.

Many students also wrote of how their service helped them to see the implications of international issues for individual human beings. In a somewhat humorous exchange, one student related how he and the father of the Bosnian family shared a cigarette while they waited at the airport for the van from the resettlement agency to arrive. Through this interaction, the young man, who had grown up in a very sheltered family, saw the humanity of someone very different than himself. My student commented that he was sure the 
Bosnian needed a cigarette badly, given his long flight, meetings with strangers, and concerns over his family and new home. (The student admitted that the uncertainty of the project and meeting the family at the airport also made him need a cigarette.) The student concluded that he personally grew from this (and other) interactions with the family as he continued to develop empathy for those negatively impacted by conflict.

Most importantly, the students' essays reflected how much they truly valued the cross-cultural experiences they had with the family. When a group of the students first visited the refugee family after the family moved to the apartment, the students were surprised by how warmly the refugees welcomed them. These students had not met the family before and the translator who was to accompany the group forgot the meeting. It shocked the students that the family invited them into the apartment since the refugees did not know the students and could not easily communicate with them. One young man wrote in his paper, "I would never let a bunch of collegeage people I did not know who could not talk to me into my house. And I certainly would not serve them coffee!" The students were amazed that the refugees trusted strangers and showed hospitality after all the conflict and distrust they had experienced. The students also expressed a desire for American society to be more welcoming.

All of the students demonstrated a great respect for refugees and an increased willingness to support their resettlement. Most students commented that the service experience had challenged their parochial attitudes and had caused them to reevaluate how they as individuals interact with those who are from different cultures and countries. The service learning experience encouraged the students to think about their responsibilities as global citizens.

\section{Assessment of the Service Exercise as a Tool of Student Learning}

Because all assessment tools have limitations, I decided the best way to determine the educational value of the service learning experience was to use a combination of assessment techniques. An admittedly subjective analysis of students' short reflective essays convinced me that 10 of the 11 students in the class had gained an awareness of other cultures and global citizenship. Student remarks like "I had the idea of a refugee family as being this group that would have nothing, they would have holes in their clothes, and they would be very needy. I was completely wrong," indicated that students had begun shedding their stereotypical views. Another student wrote that the service experience reaffirmed his desire to pursue a career in international politics. A third student related the following story: "The other day I told one of my friends about the service project and she reacted offensively to the assistance the family was getting, saying it wasn't her problem. Before this class, I would have probably agreed with her. But, I told her it's everyone's problem ...."

The reflective essays also brought to my attention an unintended consequence of the service experience. Students had the opportunity to practice democratic skills such as compromise, cooperation, and tolerance. ${ }^{3}$ It was apparent that the project helped the students learn to cooperate and communicate with each other because classroom discussions were lively and the students effectively studied together for the exams. Students wrote about how they had to practice creative communication in cross-cultural situations, especially when the translator missed some of the group's meetings with the family.

Though the essays provided rich anecdotes and reflections, I realized that the students could have written glowing statements about the service experience only to please me. To further evaluate the service experience as a teaching tool, I examined the students' performance on exam questions on topics that I had explicitly related to the service experience. I discovered that students in the 1998 class provided more correct answer to questions that covered NGOs, human rights, and ethnicity than did students in my 1997 POL 306 course, which did not have a service learning component. While differences in test performance between the 1997 and 1998 classes could relate to variations in the caliber of students or my rigor in grading, I do not believe these were the only explanatory variables. In 1998, the service helped the students to refine their understanding of select concepts in international relations.

I also assessed the service learning experience by using an evaluation instrument administered by the school's director of service learning. The vast majority of students strongly agreed that the service learning enabled them to better understand the course content. A slightly smaller number of students indicated that the service experience had sparked their interest in further serving others. I believe that students were reasonably honest on these evaluations, because $90 \%$ of the students will never take a course with the director of service learning and because the students were told that I would not see the individual evaluations.

Finally, I used student comments on the course evaluations to assess the service learning experience. Ten of the 11 students named the service as the best learning experience of the class. Many said it taught them about humanity; others said it made lessons about NGOs and global interdependence more concrete. While course evaluations can have methodological problems, I believe the majority of students were honest. Since half of the students were not political science majors and will not be my students again, they had no reason to hide their opinions about the service experience.

\section{Lessons Learned and Future Considerations}

Despite the benefits of the project, there are parts of the experience that I plan to improve. One of the problems was that students initially found it difficult to link the service experience to the topics we discussed in class. For many, this was a new type of thinking that I 
demanded. In the future, I will make a more conscious effort to direct students' learning in their interactions with the refugee family and the NGO. For example, I will give students a list of questions to think about as they observe the NGO and its activities. This should help students collect their ideas about the resettlement agency before I ask them to compare their observations with what they have read about NGOs in their textbook. This technique also should help draw more individuals into classroom discussions. Another problem was that some students felt that they spent a considerable amount of time gathering the items for the welcome pack.
In the future, I will push the students to collect and deliver the household items earlier in the semester, and to have more interactions with the family. I also will work with the resettlement agency to ensure that there are more opportunities for dialogue between the refugee family and the students.

In sum, I believe that the service experience in POL 306 creatively extended the learning process beyond the classroom. It helped me achieve the objectives of the course, for both the political science majors and general education students. Students reinforced their learning about NGOs, human rights, ethnic identity, and interdependence by encounter- ing empirical examples. The service also addressed the challenges that teachers of international politics face: It helped students to see the relevance of international politics and to appreciate the larger implications of international phenomena, and it encouraged students to evaluate the meaning of global citizenship through involvement in their community. Yet, the students were not the only ones to learn from the activity. The service experience taught me that if I challenge students to be risk takers in learning, I can empower them to gain rich insights about international politics and to more fully appreciate their roles as global citizens.

\section{Notes}

*I am grateful to Jean Abshire, Kathy Sexton-Radek, and Lynda Slimmer for their comments. A previous version of this paper was presented at the 1999 Annual Meeting of the American Political Science Association.

1. This mundane task also gave some of the students their first experiences shopping for household goods and following a budget. 2. I use the term "state," rather than "nation-state," to delineate a juridical community with a sovereign government and distinct territory. Multiple nations, or peoples with com- mon historical, communal, and national identities, can exist within one state.

3. While I discuss these ideas in my American government class, I do not address them in POL 306.

\section{References}

Barber, Benjamin, and Richard Battistoni. 1993. "A Season of Service: Introducing Service Learning into the Liberal Arts Curriculum." PS: Political Science and Politics 26(June): 235-40.

Gurr, Ted Robert, and Barbara Harff. 1994. Ethnic Conflict in World Politics. Boulder: Westview.

Henderson, Conway. 1998. International Relations: Conflict and Cooperation at the Turn of the 21st Century. New York: McGraw Hill.

Keohane, Robert, and Joseph Nye. 1989. Power and Interdependence: World Politics in Transition. 2nd ed. Glenview: Little, Brown.
Mann, Sheilah. 1999. "What the Survey of American College Freshmen Tells Us About Their Interest in Politics and Political Science." PS: Political Science and Politics 32(June): 263-68.

Nye, Joseph. 1990. Bound to Lead: The Changing Nature of American Power. New York: Basic Books.

—. 2000. "The Power We Must Not Squander." The New York Times, January 3, A19.

Rhoads, Robert, and Jeffrey Howard, eds. 1998. Academic Service Learning: A Pedagogy of Action and Reflection. San Francisco: Jossey-Bass.

Rourke, John. 1999. International Politics on the World Stage. 7th ed. New York: Dushkin McGraw-Hill.

Trudeau, Robert. 1997. "Service Learning and Comparative Politics: A Latin American Saga." In Experiencing Citizenship: Concepts and Models for Service-Learning in Political Science, ed. Richard Battistoni and William Hudson. Washington, DC: American Association of Higher Education.

U.S. Bureau of the Census. 1997. "Voting and Registration: Novenber 1996" $<$ www.census.gov/population/socdemo/ voting/history/vot23.txt > November 1996.

Wiarda, Howard. 1996. American Foreign Policy. New York: Harper Collins. 